\title{
Dispute Resolution of Violation of Indonesian Forest Area Based on the Decision of The Supreme Court Number 269 K / TUN / 2018
}

\author{
Aris Irawan \\ Universitas Borneo Tarakan, Kalimantan Utara, Indonesia \\ Email: fatherdosen@gmail.com
}

\section{ARTICLE INFO}

Date received : 02 January 2021

Revision date : 01 February 2021

Date received : 05 March 2021

\section{Keywords:}

Dispute Resolution

Forest Area

Decision

\begin{abstract}
This research aimed at analyzing the characteristics of resolution of forest area disputes based on the Decision of the Supreme Court Number 269K / TUN / 2018. This research used normative legal method with legal, case, and conceptual approaches. The results showed that the Decidendi Ratio of the Supreme Court's Decision was inappropriate. It is because in the context of the principle of legal certainty, that the object of the dispute is not included in the PTUN Decree, because of the Decree of the Minister of Agrarian Affairs and Spatial Planning / Head of the National Land Agency Number 1 / Pbt / KEM-ATR / BPN / 2016, is an integral part of the execution of criminal law against the act of falsifying documents carried out by officials within the North Kalimantan National Land Agency (formerly East Kalimantan), in issuing the PT Nunukan Jaya Lestari HGU certificate. The Supreme Court's consideration regarding the overlapping area between PT Adindo Hutani Lestari and PT Nunukan Jaya Lestari, covering $\pm 3,500 \mathrm{Ha}$ is also incorrect because it must be understood that the area claimed to be overlapping is a dispute of the forest area.
\end{abstract}

\section{INTRODUCTION}

Forest is an integrated ecosystem; a land is containing biological natural resources dominated by trees in their natural environment, which cannot be separated from one another. Based on its status, the forest consists of state forest and private forest. The state forest is forest located on land that is not encumbered with land rights, while the private forest is forest located on land encumbered with land rights. So far, legal certainty of ownership of land rights for individuals or legal entities has been influenced by the land registration system adopted by Indonesia, which is a negative system. According to this system, everything stated in a land certificate is considered true until it can be proven. The negative system will produce letters of proof of rights that act as a strong means of proof. As a consequence of adopting a negative system, parties who feel they have rights can file a lawsuit against the party whose name is listed on the certificate. However, in order to maintain legal certainty for issued land title certificates, it is explained in the formulation of Article 32 Paragraph (2) of Government Regulation Number 24 of 1997 concerning Land Registration, that the opportunity for parties who feel entitled to land is limited to only a period of 5 (five) years since the issuance of the land certificate to take legal action to defend its rights.

A different reality is experienced by land rights holders whose land area is either partially or wholly designated as forest areas by the Government, in this case the Minister in charge of forestry affairs. Legal certainty of ownership / control over land simply disappears and it is taken over by the state to become a forest area. 
This is because the definition of forest area in Law Number 41 Year 1999 concerning Forestry (hereinafter referred to as UUK) is formulated as follows: "Forest area is a certain area designated and / or stipulated by the government to maintain its existence as permanent forest."

Based on this definition, it can be concluded that land designated as forest area, both certified and uncertified, can be equated with forest areas that have been determined (Soelthon, 2018). Although it is further explained in Article 14 of the UUK that legal certainty over forest areas can be guaranteed after forest area confirmation is carried out through the following stages: forest area designation, forest area boundary demarcation, forest area mapping and forest area designation. Referring to these provisions, the areas designated by the government as forest areas should not have legal certainty as forest areas because they are only in the early stages of confirmation of forest areas.

The Forest areas that are still in the designation stage cannot be used as a reference as permanent forest areas, it is considering that forest area designation is only done on paper based on the coordinates contained in the attachment to the forest area designation decree. It can create problems because in some areas, forest areas overlap with the rights of third parties. The rights of third parties include, Ownership Rights, Business Use Rights (HGU), Building Use Rights (HGB), Use Rights, Management Rights and other written evidence that is recognized and in accordance with laws and regulations in the land sector.

An example is HGU Number 01 dated May 13, 2003 on behalf of PT. Nunukan Jaya Lestari in North Kalimantan Province, which overlaps with a forest area with the function of Limited Production Forest (hereinafter referred to as HPT) based on the Decree of the Minister of Forestry Number SK.718 / Menhut-II / 2014 dated 29 August 2014 concerning Forest Areas in East Kalimantan and Kalimantan Provinces North and even the forest area has been burdened with a Business Permit for Utilization of Industrial Forest Timber Forest Products (IUPHHK$\mathrm{HTI}$ ) on behalf of PT. Adindo Hutani Lestari.

Apart from HGU, there are also Freehold Certificates (hereinafter referred to as SHM) which overlap with forest areas. For example SHM Number 106 dated 19 June 1981 in the name of M. Rustam and SHM Number 484 dated 23 August 2005 in the name of $\mathrm{H}$. Ruslan Abdul Gani in South Kalimantan which overlaps with a forest area with the function of Permanent Production Forest (hereinafter referred to as HP) based on a Ministerial Decree. Forestry Number SK.435 / Menhut-II / 2009 dated 23 July 2009 concerning Designation of Forest Areas in South Kalimantan Province.
In Law Number 5 of 1960 concerning Basic Agrarian Principles (hereinafter referred to as UUPA), HGU and SHM are evidence of land rights management, in addition to other evidence as referred to in Article 16 Paragraph (1) of the UUPA, where the HGU holder and SHM is given the authority to use the land concerned for the purpose of directly using the land. The common thread that can be drawn on the overlapping issue between HGU and SHM as well as other land rights with designation of forest areas is the similarity of objects of land which are encumbered with land rights and those designated as forest areas. Where land rights and designation of forest areas are both carried out on state land. So that many land rights are granted and forest area designations occur in the same area.

If the designation of a forest area is carried out before the land is encumbered with land rights, then it is clear that the issuance of the land rights is not in accordance with the procedure for granting land rights where if the land to be granted land rights is a forest area, then granting rights to the land can be carried out and if the land to be granted land rights is issued from the forest area (Amos, 2007).

Therefore, the research problem of this study is formulated as follows:

1. Characteristics of resolution of forest area violation dispute in Indonesia based on Supreme Court Decision Number 269K / TUN / 2018;

2. The legal basis for the judge in the Supreme Court Decision Number 269K / TUN / 2018 dated 7 June 2018;

\section{METODE}

This research is normative legal research, namely legal research carried out by researching and examining statutory regulations including research on legal principles, legal systematics, legal synchronization levels, and legal history governing the granting of business utilization permits and community forest.

\section{RESULTS AND DISCUSSION}

A. Analysis of the characteristics of forest area violation dispute resolution based on Supreme Court Decision Number 269K / TUN / 2018 in Indonesia.

Article 1 number 10 of Law Number 51 of 2009 concerning Second Amendment to Law Number 5 of 1986 concerning State Administrative Courts regulating state administrative disputes is a dispute that arises in the field of state administration between a 
person or civil legal entity and an entity or state administrative officials, both at the central and regional levels, as a result of the issuance of state administrative decisions including employment disputes based on the prevailing laws and regulations. Apart from that, Article 1 point 12 regulates that the disputing parties are individuals or civil legal entities with state administrative bodies or officials, both at the central and regional levels. Defendant is a state administrative body or official who issues a decision based on the authority available to him or delegated to him who is being sued by a civil person or legal entity.

The reasons that can be used in filing a lawsuit are regulated in Article 53 paragraph 2 of Law Number 9 of 2004 concerning Amendments to Law Number 5 of 1986 concerning State Administrative Courts is that the state administrative decision being sued is contrary to the prevailing laws and regulations; and the state administrative decision being challenged is against the general principles of good governance. Lawsuits are also filed within a grace period of 90 days from the receipt or announcement of the Decree of the State Administrative Agency or Official. For the party whose name is stated in the State Administrative Decree being sued, the 90 day grace period is calculated from the day the State Administrative Decree being challenged is received.

The State Administrative Court also applies the presumption of innocence as contained in the criminal procedural law. A State Administration official prior to a judge's decision who has permanent legal force stating that he is wrong in making a State Administrative Decree or in other words a State Administration Decree is still considered valid (not against the law), before a judge's ruling has power permanent law which declares the decision invalid (against the law). Therefore, a State Administration Decree can be sued will not cause delays in the implementation of the decision.

Article 72 of Law no. 5 of 1986 concerning State Administrative Courts regulates the trial in absentia or the trial takes place without the presence of the defendant. In the event that the defendant or his attorney is not present at the trial twice in a row and / or does not respond to the lawsuit without a justifiable reason even though each time it has been properly summoned, the Chief Judge of the trial with a letter of determination asks the defendant's superior to order the defendant to be present and / or respond to the lawsuit. In the event that after two months have passed after being sent by registered letter of the ruling as intended, no news is received from both the defendant's and the defendant's superior, the trial judge determines the day for the next trial and the dispute examination will be continued according to the normal procedure, without the defendant's presence. A verdict on the subject of the claim can be passed only after a thorough examination of the evidentiary aspect has been carried out (Anonim, 2010).

The dispute settlement process is carried out through the court or what is often referred to as "litigation", which is a dispute settlement carried out by proceeding in court where the authority to regulate and decide is exercised by the judge. This dispute resolution process resulted in all disputing parties facing each other to defend their rights in court. The final result of a dispute resolution through litigation is a decision stating a win-lose solution.

Conventional dispute resolution carried out through a court has been carried out for hundreds of years or even thousands of years ago. The settlement of land disputes whether they are submitted to the general court in civil or criminal terms through the courts. If the dispute is regarding illegal land settlement or illegally allowed by Government Regulations in Lieu of Law No. 51 of 1960 concerning the Prohibition of Use of Land without a Rightful Permit or Proxy, the settlement is through the state administrative court.

In the context of dispute resolution decided by the Supreme Court through the Supreme Court Number 269K / TUN / 2018, the dispute resolution is resolved through a litigation mechanism. This is because the dispute that took place between PT Nunukan Jaya Lestari versus PT Adindo Hutani Lestari and the Minister of Agrarian and Spatial Planning / Head of the National Land Agency was resolved through the judiciary, which at the end point of the dispute's journey had reached the peak of dispute resolution by the highest judicial institution, namely Supreme Court.

It is considering that the object of dispute is included in the realm of state administration, it can be said that this State Administration dispute has characteristics that are also distinctive when compared to other disputes in general, especially those related to the principles applicable in the law of procedure. The legal principles that apply to State Administration dispute resolution (TUN) are: The principle of presumption of innocence (vermoeden van rechtmatigheid or praesuptio 
iustae causa), the principle of free proof (vrij bewijs), the principle of the activeness of the judge (dominus litis), the principle of court decisions having legally binding as "erga omnes". Although the substance of the plaintiff's lawsuit is civil in nature, the State Administration dispute is a public legal dispute. Therefore, the decision of the State Administrative Court must apply generally to anyone, not only limited to the disputing parties (Fuady, 2005).

The relationship between the legal principles of the state administrative court to exercise control over government actions in the field of public law must pay attention to the following characteristics:

1) The characteristics of a state administration decision which always contains the principle of praesumptio iustae causa, namely a State Administrative Decree (Beschikking) must always be considered valid as long as it has not been proven otherwise so that in principle it must always be implemented immediately;

2) The principle of protection of the public or public interest that stands out in addition to the protection of individuals;

3) The principle of self-respect or selfobedience of government officials towards administrative court decisions, because there are no direct coercion attempts through bailiffs as is the case in civil law procedures.

The Supreme Court Decision Number 269K / TUN / 2018 is a decision to resolve litigation disputes characterized as state administrative disputes. The Supreme Court as the last bastion or as the highest peak of the level of judicial institutions in Indonesia, it must be understood that the Supreme Court in issuing legal considerations is not based on legal facts (judex facti), as in the first level court and the level of appeal, but The Supreme Court itself decides the case (petitum), is based on the application of law or observes whether or not the application of law (judex jure) is in a court that is below its level.

The existence of the Supreme Court Decision Number 269K / TUN / 2018, is to decide on the dispute case regarding the Decree Number 1 / Pbt / KEM-ATR / BPN / 2016 dated July 25, 2016 concerning the Cancellation of Business Use Rights Number 01 / Nunukan Barat dated May 132003 on behalf of PT Nunukan Jaya Lestari on an area of $19,974,130$ ha. The fulcrum for the dispute over SK Number 1 / Pbt / KEM-ATR / BPN / 2016 dated July 25, 2016, is related to administrative decisions issued by TUN officials, in this case the Minister of Agrarian Affairs and Spatial Planning / Head of the National Land Agency, if It is analyzed that the TUN decision was born due to an administrative violation committed by PT Nunukan Jaya Lestari where this company according to the interpretation of the minister of agararia and spatial planning, as a TUN official has controlled the land which is called plantation land but in fact the land is categorized as a production forest area.

According to the interpretation of the Minister of Agrarian Affairs and Spatial Planning / Head of the National Land Agency that there are indications of forest area violations by PT Nunukan Jaya which is viewed from an administrative perspective, due to the facts in the field based on the results of joint research in the field from an integrated team, the plantation area of PT Nusa Jaya Lestari ( PT NJL) according to HGU No. 01 dated May 12, 2003, it is known that the HGU location claimed by PT NJL has an area of $\pm 19,974.13$ hectares, of which $\pm 17,092.26$ hectares is located in the Forest Zone with the function of Production Forest.

The results of the author's research prove that the dispute resolution is related to administrative decisions from state administration officials, in this case the Minister of Agrarian Affairs and Spatial Planning / Head of the National Land Agency, the content of the decision is the Cancellation of Business Use Rights No. 01 / West Nunukan on behalf of PT Nunukan Jaya Lestari with an area of $19,974,130$ ha, located in Nunukan Barat Village, Nunukan District, Nunukan Regency, North Kalimantan Province. The cancellation of the HGU by the minister, for PT NJL, is considered an adverse administrative decision.

The dispute decided by the Supreme Court, of course, has tested it according to the applicable laws and regulations based on Law Number 5 of 1986 in conjunction with Law No. 9 of 2004 concerning State Administrative Courts in Article 53 paragraph 1 and paragraph 2 letters $a, b$. In Article 1, it is stated that if there is a person or legal entity who feels that their interests have been harmed by a TUN Decree, they can submit a written suit to the competent Court containing demands that the disputed TUN Decree be declared null and void, with or without a claim for compensation and / or rehabilitation therefore the Party who feels aggrieved. 
B. Analysis of the legal basis of judges in the Supreme Court Decision Number 269K / TUN / 2018 dated 7 June 2018.

In general, the function of the ratio decidendi or legal reasoning is as a means of presenting points of thought about the problems of legal conflicts between one person and another, or between the community and the government on cases that become controversial or counterproductive to become replicas and duplicates of examples, especially concerning the good and bad of the system of law enforcement and implementation, the attitudes of the legal apparatus and the judiciary.

Whereas the format of the ratio decidendi in the judge's decision is stated in a legal proposition. Proposition in this context is a premise that contains judges' considerations. This proposition can be expressed explicitly or implicitly. This reminds us of another definition of the ratio decision from Sir Rupert Cross in the book 'Precedent in English Law' which states that "Any rule expressly or impliedly treated by the judge as a necessary step in reaching his conclusion" means that every rule expressed or implied which is applied by the judge as a necessary step in reaching a conclusion.

Based on the legal considerations of the panel of judges at the Supreme Court, the authors summarize the main points of the decidendi ratio from the Supreme Court judge's decision, as follows:

1) The decision to cancel the HGU by the Minister of Agrarian Affairs and Spatial Planning / Head of the National Land Agency according to the considerations of the panel of judges of the Supreme Court may adversely affect the decision holder, namely PT Nunukan Jaya Lestari;

2) The Court considers that the cancellation of the PT Nunukan Jaya Lestari HGU certificate, through the Decree of the Minister of Agrarian Affairs and Spatial Planning / Head of the National Land Agency, there is a substantive administrative legal flaw, because the land that the HGU has canceled is an area that overlaps with the area claimed. by PT Adindo Hutani Lestari, the object of the dispute must be canceled, not in the category of material dispute object.

Based on the 2 decidendi ratios, the court issues a petitum or amar of the following rulings:

1) Declare the cancellation of the Decree of the Minister of Agrarian and Spatial Planning / Head of the National Land Agency Number 1 /
Pbt / KEM-ATR / BPN / 2016 dated 25 July 2016 concerning Cancellation of Business Use Rights Number 01 / Nunukan Barat dated 13 May 2003 on behalf of PT Nunukan Jaya Lestari covering an area of $19,974,130$ hectares is located in Nunukan Barat Village, Nunukan District, Nunukan Regency, North Kalimantan Province (formerly East Kalimantan);

2) Require the Minister of Agrarian Affairs and Spatial Planning / Head of the National Land Agency to revoke the Decree of the Minister of Agrarian and Spatial Planning / Head of the National Land Agency Number 1 / Pbt / KEMATR / BPN / 2016 dated July 25, 2016 concerning Cancellation of Business Use Rights Number 01 / Nunukan Barat dated May 13, 2003 on behalf of PT Nunukan Jaya Lestari covering an area of 19,974,130 hectares located in Nunukan Barat Village, Nunukan District, Nunukan Regency, North Kalimantan Province (formerly East Kalimantan); Obliged to the Minister of Agrarian Affairs and Spatial Planning / Head The National Land Agency issued a Decree on the Cancellation of Business Use Rights Certificate (HGU) Number 1 / Nunukan Barat dated May 13, 2003 on behalf of PT Nunukan Jaya Lestari with an area of \pm 3,500 Ha. which overlaps with the area of Business Permit for Utilization of Timber Forest Products - Industrial Plantation Forest (IUPHHK-HT) on behalf of PT Adindo Hutani Lestari and simultaneously issues a Decree on Granting Business Use Rights covering an area of $\pm 16,474,130 \mathrm{Ha}$. to PT Nunukan Jaya Lestari;

3) Require the Minister of Agrarian Affairs and Spatial Planning / Head of the National Land Agency to issue a Decree on the Cancellation of Business Use Right Certificate (HGU) Number 1 / Nunukan Barat dated May 13, 2003 on behalf of PT Nunukan Jaya Lestari, with an area of \pm 3,500 Ha. which overlaps with the area of Business Permit for Utilization of Timber Forest Products - Industrial Plantation Forest (IUPHHK-HT) on behalf of PT Adindo Hutani Lestari and at the same time issued a Decree on Granting Business Use Rights covering an area of $\pm 16,474,130 \mathrm{Ha}$. to PT Nunukan Jaya Lestari.

Observing the Decidendi Ratio (legal considerations) of the panel of judges of the Supreme Court as stipulated in the Supreme Court Decision Number 269 K / TUN / 2018 dated June 7 2018, according to the author's analysis of the decidendi ratio, if it is related to forest area violations, that the deciden ratio is not quite right , so that the decision issued by the Minister of Agrarian and Spatial Planning / Head of the 
National Land Agency through the Decree of the Minister of Agrarian and Spatial Planning / Head of the National Land Agency Number 1 / Pbt / KEMATR / BPN / 2016 dated July 25, 2016 concerning Cancellation of Business Use Rights Number 01 / Nunukan Barat dated May 13, 2003 on behalf of PT Nunukan Jaya Lestari, is correct (Veronica, 2015).

According to the author, it is inaccurate, the Supreme Court's legal considerations in the first dictum are "having a detrimental impact on decision-holders". According to the author (Sudjito, n.d.), when viewed from the point of view of the General Principles of Good Governance (AAUPB) or Algemene Beginselen van Behoorlijk Bestuur or Good Governance, the cancellation of the HGU is appropriate. From the AAUPB's point of view, the thing that is usually put forward is the principle of legal certainty as an integral part of the AAUPB itself. In the context of state administration by state apparatus, in this case state administration officials, a state administration decision issued within the framework of the AAUPB is not allowed to abandon a principle known as the principle of legal certainty. This principle is an integral part of the AAUPB itself (Seyyed, n.d.).

In this connection, the TUN decision in the context of AAUPB, was born as a form of legal protection and used as an instrument to increase legal protection for citizens from government action. This means that the existence of AAUPB in government administration is as a guide or guide for the government or state administrative officials in the framework of good governance. Muin Fahmal stated that the general principles of proper governance are actually the guidelines for state administrators in carrying out their duties. These signs are needed so that actions remain in accordance with the true objectives of the law, so that the AAUPB can be likened to a traffic sign and a travel guide in order to facilitate government relations, namely between the government and the governed or members of the community. The AAUPB is then used as a basis for assessment and administrative efforts, and as an unwritten legal norm for government actions when it is about to issue decisions of an administrative nature (Indroharto, 1993).

It is in the context of this discussion that the author wants to emphasize that AAUPB has the following important functions and meanings:

1) For state administration, it is useful as a guide in interpreting and applying vague, vague or unclear statutory provisions. Except that at the same time limiting and avoiding the possibility of state administration using freies ermessen / implementing policies that deviate far from statutory provisions. Thus, the state administration is expected to avoid the actions of onrechtmatige daad, detournement de pouvoir, abus de droit, and ultravires;

2) For citizens, as justice seekers, AAUPB can be used as a basis for a lawsuit as referred to in article 53 of Law Number 5 Year 1986.

3) For TUN Judges, it can be used as a means of testing and canceling decisions issued by TUN bodies or officials;

4) AAUPB is also useful for the legislative body in drafting a law.

So according to the author's argument for the panel of judges at the Supreme Court when deciding the case in casu PT Nunukan Jaya Lestari against the Minister of Agrarian Affairs who in the petitum declared the Decree of the Minister of Agrarian and Spatial Planning / Head of the National Land Agency Number 1 / Pbt / KEM-ATR / BPN / 2016 dated 25 July 2016 concerning the Cancellation of Business Use Rights Number 01 / Nunukan Barat dated 13 May 2003 on behalf of PT Nunukan Jaya Lestari covering an area of $19,974,130$ hectares located in Nunukan Barat Village, Nunukan District, Nunukan Regency, North Kalimantan Province (formerly Kalimantan East), at least in legal considerations, one must pay attention to the important principles that underlie the birth of a TUN official decision, namely the principle of legal certainty which is the foundation for the establishment of the AAUPB (Solechan, 2019).

The author analyzes the case of PT Nunukan Jaya Lestari against the Minister of Agrarian Affairs, so there are several legal facts that should be new findings for the panel of judges from the Supreme Court, namely: the process of issuing HGU owned by PT NJL, was born from an illegal act criminal responsibility can be asked, so that in terms of the principle of legal certainty, it can be seen that the issuance of the HGU has administrative defects as stated by the Minister of Agrarian and Spatial Planning / Head of the National Land Agency, as the author quotes in the First Level Administrative Court Decision as follows:

That from the process of issuing the Right to Use Business Certificate No. 1 / West Nunukan on behalf of PT. Nunukan Jaya Lestari, which was not in accordance with the procedure, resulted in a criminal case making forged letters, as referred to in the criminal decision of the Samarinda District Court No. 140 / Pid.B / 2013 / PN.Smda Jo. No. 33 / Pid / 2014 / PT.Smda, with the defendant Sukodi, $\mathrm{SH}$ bin Domo Kartika (former Head of the Land Rights Division of the Regional Office of the East Kalimantan National Land Agency as a member of Committee $B$ and the criminal 
verdict of the Samarinda District Court No. 141 / Pid.B /2013/PN.Smda, with the defendant Purwanto, SH bin Mulyo Rejo (former Head of the Section for the Granting of Rights to Legal Entities of the East Kalimantan Regional Office of the National Land Agency as the Secretary of Committee B), whose anger stated that the defendant Sukodi, SH bin Domo Kartika and Purwanto, SH bin Mulyo Rejo was legally proven and convicted of guilt of committing a criminal act by jointly making false papers and imposing a sentence on the defendant with imprisonment for 6 (six) months. Both criminal decisions have permanent legal force (Amriani, 2014).

Whereas in legal consideration the criminal verdict of the Samarinda District Court No. 140 / Pid.B / 2013 / PN.Smda Jo. No. 33 / PID / 2014 / PT.Smda and decision No. 141 / Pid.B / 2013 / PN.Smda, the defendant Sukodi, S.H bin Domo Kartika and Purwanto, S.H bin Mulyo Rejo, explained that the Minutes of the Committee for Land Examination B No. 01 / RPT-PAN.B2003 dated 12 March 2003 was made not based on actual field physical facts, as referred to in the Minutes of Location Inventory Results dated February 10, 2003 which became one of the references to be brought to the committee meeting $B$, it was explained the condition of the land being requested for locations that have not yet been opened, there are 3 (three) years old Industrial Plantation Forest (acacia trees) belonging to PT. Adindo Hutani Lestari covering an area of $+1,400 \mathrm{Ha}$, but in the conclusion of the Minutes of the Soil Inspection Committee B No. 01 / RPT-PAN.B2003 dated March 12, 2003, it was not included / it was not stated that the requested location contained acacia plants belonging to PT. Adindo Hutani Lestari covering an area of $+1,400$ hectares, so that the area of land use rights for PT. Nunukan Jaya Lestari is partly located in the area of PT. Adindo Hutani Lestari resulted in a lost opportunity for PT. Adindo Hutani Lestari to manage acacia plants and the overlapping land of PT. Nunukan Jaya Lestari with Industrial Plantation Forest Concession land owned by PT. Adindo Hutani Lestari ... "

So according to the author's argument, the existence of the Decree of the Minister of Agrarian and Spatial Planning / Head of the National Land Agency Number 1 / Pbt / KEMATR / BPN / 2016 dated 25 July 2016 concerning Cancellation of Business Use Rights Number 01 / Nunukan Barat dated May 13, 2003 on the name PT Nunukan Jaya Lestari, is an integral part of the criminal execution to cancel the PT NJL HGU certificate, because the issuance of the PT NJL HGU certificate in question, in the issuance process there is an element of criminal action, so that in the context of upholding the principle of legal certainty, the Decree of the Minister of Agrarian Affairs and Administration Room / Head of the National Land Agency Number 1 / Pbt / KEM-ATR / BPN / 2016, is not in conflict with AAUPB. So the ratio decidendi of the court which states on the grounds that ... it can have a detrimental impact on the decision-holder ... is not correct, because according to the author, once again what must be considered or used as a legal reason is by referring to the principle of legal certainty that the basis of The issuance of the Decree of the Minister of Agrarian and Spatial Planning / Head of the National Land Agency Number 1 / Pbt / KEM-ATR / BPN / 2016 is included in the category of part of the criminal law execution decision, so it cannot be used as the object of a PTUN dispute (Yuslim, 2015).

From the author's explanation, it can be concluded that the Decidendi Ratio of the Supreme Court Decision Number 269 K / Tun / 2018 is not appropriate, as the basis for producing a petitum which decrees that "Decree of the Minister of Agrarian and Spatial Planning / Head of the National Land Agency Number 1 / Pbt is canceled. / KEM-ATR / BPN / 2016 dated 25 July 2016 concerning Cancellation of Business Use Rights Number 01 / Nunukan Barat dated 13 May 2003 on behalf of PT Nunukan Jaya Lestari covering an area of $19,974,130$ hectares located in Nunukan Barat Village, Nunukan District, Nunukan Regency, Province North Kalimantan (formerly East Kalimantan) ".

According to the author's analysis, the Decree of the Minister of Agrarian and Spatial Planning / Head of the National Land Agency Number 1 / Pbt / KEM-ATR / BPN / 2016 dated 25 July 2016 concerning the Cancellation of Business Use Rights Number 01 / Nunukan Barat dated 13 May 2003 on behalf of PT Nunukan Jaya Lestari covering an area of $19,974,130$ hectares is located in Nunukan Barat Village, it is appropriate, considering that PT Nunukan Jaya Lestari, was proven to have committed violations of forest areas, both from a criminal law perspective and from an administrative law perspective. From a criminal law point of view, the violation is the basis for the issuance of the PT Nunukan Jaya Lestari HGU certificate, based on physical data falsified by individuals at the BPN Office (formerly still BPN East Kalimantan), while from an 
administrative law point of view, the plantation permit received by PT NJL in Production Forest Areas, which should have been exchanged for forest areas, as regulated in Article 49 of Government Regulation Number 104 of 2015 concerning Procedures for Changing the Designation and Function of Forest Areas, but in fact, the exchange of forest areas is not carried out by PT Nunukan Jaya Lestari. That is, it is at this point in the opinion of the author that PT Nunukan Jaya Lestari has committed a violation against the forest area.

\section{CONCLUSION}

The characteristics of dispute resolution of forest area violation in Indonesia which refer to the Supreme Court Decision Number 269K / TUN / 2018, are dispute resolution with a litigation model that has the characteristics of state administrative or administrative disputes, because the object of the dispute is the State Administration decision, namely a letter Decree of the Minister of Agrarian Affairs and Spatial Planning / Head of the National Land Agency Number 1 / Pbt / KEM-ATR / BPN / 2016 dated 25 July 2016 concerning Cancellation of Business Use Rights Number 01 / Nunukan Barat dated 13 May 2003 on behalf of PT Nunukan Jaya Lestari covering an area of $19,974,130 \mathrm{Ha}$ located in Nunukan Barat Village; (ii) Decidendi Ratio The Supreme Court Decision Number: 269 K / TUN / 2018 dated 7 June 2018, states as follows: that the Decree of the Minister of Agrarian and Spatial Planning / Head of the National Land Agency regarding the Cancellation of HGU PT Nunukan Jaya Lestari, could have a detrimental impact on the holder the decision was PT Nunukan Jaya Lestari.

Then according to the court that there is a substantive administrative legal flaw, because the land that the HGU has been canceled is an area that overlaps with the area claimed by PT Adindo Hutani Lestari, then the object of the dispute must be canceled, not in the category of material dispute object. According to the author's analysis, the Decidendi Ratio of the Supreme Court's decision is not quite right. First, in the context of the principle of legal certainty, that the object of dispute is not included in the PTUN Decree, because the Decree of the Minister of Agrarian and Spatial Planning / Head of the National Land Agency Number 1 / Pbt / KEM-ATR / BPN / 2016, is an integral part of the execution of criminal law against The act of document forgery committed by officials within the North Kalimantan National Land Agency (formerly East Kalimantan), in issuing the PT Nunukan Jaya Lestari HGU certificate, proved that the physical data as the basis for the birth of the HGU for PT NJL, did not match the actual facts, because it was proven to be falsified by unscrupulous officials within the East Kalimantan BPN environment, based on a State Court Decision which has permanent legal force. The Supreme Court's consideration regarding the overlapping area of the area between PT Adindo Hutani Lestari and PT Nunukan Jaya Lestari, covering an area of \pm 3,500 hectares, is also inaccurate, because it must be understood that the area claimed to be the overlap is a representation that PT Nunukan Jaya Lestari has committed violations of forest area violations, due to the fact that PT Nunukan Jaya Lestari, made forest areas into oil palm plantation areas, without exchanging forest areas, as regulated in Article 49 of Government Regulation Number 104 of 2015 concerning Procedures for Changing the Designation and Function of Forest Areas.

\section{REFERENCES}

Amos. (2007). Legal Opinion Theorities and Empirisme. Jakarta.

Amriani, N. (2014). Alternatif Penyelesaian Sengketa dan Arbitrase (Ketiga). Jakarta.

Anonim. (2010). Peranan Putusan Pengadilan dalam Program Deradikalisasi Terorisme di Indonesia. Indonesia.

Fuady, M. (2005). Pengantar Hukum Bisnis: Menata Bisnis Modern di Era Global. Bandung: Citra Aditya Bakti.

Indroharto. (1993). Usaha Memahami UndangUndang Peradilan Tata Usaha Negara. Jakarta: Pustaka Sinar Harapan.

Seyyed, H. N. (n.d.). Man and Nature: The Spiritual Crisis of Modern Man. London: George Allen And Unwin Ltd.

Soelthon, G. N. (2018). Silang Sengkarut Pengelolaan Hutan dan Lahan di Indonesia. Bogor: Forest Watch Indonesia.

Solechan, Solechan. (2019). Asas-Asas Umum Pemerintahan yang Baik dalam Pelayanan Publik. Administrative Law and Governance Journal, 2(3), 541-557.

Sudjito. (n.d.). Pancasila sebagai Paradigma IImu Hukum Indonesia. Kumpulan Makalah Seminar Hukum dan Konstitusi, Mahkamah Konstitusi, Republik Indonesia dan Pusat Studi Pancasila UGM. yogyakarta.

Veronica, Nuri Widiastuti. (2015). Rivalitas Cina dan Jepang dalam Institusi Regional Asia Timur. Global: Jurnal Politik Internasional, 16(1), 1933. 
